\title{
Compressive residual strength at low temperatures of composite laminates subjected to low-velocity impacts
}

\author{
S. Sánchez-Sáez*, E. Barbero, C. Navarro \\ Department of Continuum Mechanics and Structural Analysis, University Carlos III of Madrid, Avda. de la Universidad 30, \\ 28911 Leganés, Madrid, Spain
}

\begin{abstract}
Compression after impact behaviour of different carbon fibre reinforced composite laminates (tape and woven) was studied at low temperatures. Low velocity impact tests on thin plates at room temperature were made, followed by compression after impact tests at $60{ }^{\circ} \mathrm{C}$ and $150{ }^{\circ} \mathrm{C}$. The results of these tests were compared with those of non impacted specimens to study the variation of the residual strength at different impact energies. In tape laminates, the lower temperature decreased compression after impact strength, although no influence was detected regarding temperature in the variation of the compressive strength retention factor. However, at low temperatures, the woven laminate showed greater strength and a less loss of the retention factor than at room temperature.
\end{abstract}

Keywords: Compression after impact; Thin laminates; Low temperature; Residual strength; Carbon fibre laminates

\section{Introduction}

Composite materials, mainly carbon fibre/epoxy laminates, are being widely used to manufacture structural components that are exposed to low temperature environments in aeronautical and aerospace applications [1]. Competition between aeronautical constructors has stimulated the use of composites in primary structures (wings or fuselages), as in the future Airbus 350 or Boeing 787. In addition, the use of composites in the manufacture of cryogenic fuel tanks is one of the most promising technologies to decrease the weight of the future reusable launch space vehicles [2 5].

In these structural components, unidirectional laminates are not normally used because of the high anisotropy of their mechanical properties; multidirectional laminates, basically quasi-isotropic and woven, are optimal for different load conditions [6]. Although the use of cross-ply laminates in industrial applications is less usual, it would be

\footnotetext{
* Corresponding author. Tel.: +34 9162488 82; fax: +34 916249430.

E mail address: ssanchez@ing.uc3m.es (S. Sánchez Sáez).
}

helpful to know the behaviour of the components manufactured from these laminates, since these multidirectional ones are the easiest to make and direct comparisons could be established with the plain-woven laminates [7].

Unfortunately, composite laminates have low resistance under dynamic loading, particularly impact loading, which can significantly reduce their mechanical properties [8]. Structural components may undergo low- and high-velocity impact loading during their manufacture, assembly, maintenance or service life (runaway debris, bird strikes, dropped wrench, etc.), low-velocity impacts being considered more dangerous. Low-velocity impact damage occurs mainly in the form of delamination, which may involve single or multiple internal cracks parallel to the surface of the structure or component. Under compressive loading, this local delamination may grow and lead to global failure of the structure at a load well below that of the design level [9]. Several researchers [ll 10 13] have shown that the compressive-strength in a damaged component may have only $40 \%$ of that of an undamaged structural element.

Therefore, for an appropriate design, it is important to ensure that the residual strength of a damaged structure 
is sufficient either for service until the damage is detected or for the rest of the service life of that structure. For this reason, numerous studies have examined the behaviour of composite laminates subjected to low-velocity impacts and compression after impact, mainly at room temperature [11 18].

Most low-velocity impacts occur during maintenance or assembly operations, and thus at ambient temperature, but the damaged components may work under low temperatures during their service life, exposed to air at $-60{ }^{\circ} \mathrm{C}$ or in space at $-150^{\circ} \mathrm{C}[8,19]$. Great changes in the structure, properties and failure mechanisms of composite materials can occur when they are exposed to low temperatures [20 22]. Some authors have pointed out that in carbon fibre composites the reduction of temperature may increase the compressive and tensile strength in the fibre direction [23], whereas others report reductions in compressive [24] or tensile strength [2]. Consequently, it is necessary to determine the mechanical behaviour of these components damaged at ambient temperature when the temperature in service is very low. Bibliographical references have not been found about this matter.

In this paper, a study is made of the compressive residual strength at low temperatures of carbon/epoxy laminates of different configurations: cross-ply $[0 / 90]_{3 \mathrm{~S}}$, quasi-isotropic $[ \pm 45 / 0 / 90]_{S}$ and woven (10 plies). First, low-velocity impact tests were made at ambient temperature, damaging the specimens and afterwards the effects of that damage on the compressive strength of the laminates exposed at low temperatures were analysed.

\section{Experimental tests}

\subsection{Materials}

Three different carbon/epoxy laminate lay-ups were tested: a cross-ply $[0 / 90]_{3 \mathrm{~S}}$ and a quasi-isotropic laminate $[ \pm 45 / 0 / 90]_{S}$, both manufactured from unidirectional preimpregnated sheets of AS4/3501-6, and a laminate of ten plain-woven plies, AGP-193-PW/8552.

All the laminates were manufactured by SACESA (Spain) using prepegs of Hexcel Composite Materials with a volumetric fibre content of $60 \%$, following all the requirements of the aeronautic industry.

\subsection{Low-velocity impact tests}

Low-velocity impact tests were performed at room temperature using a drop-weight tower, CEAST Fractovis 6785. Square specimens of $78 \mathrm{~mm} \times 78 \mathrm{~mm}$ were tested. The impactor had a semi-spherical tip of $20 \mathrm{~mm}$ of diameter and a total mass of $3.62 \mathrm{~kg}$.

Four different impact energies were exerted on each laminate (Table 1). All energies were below the one that produces the perforation of the laminate. As the laminates were of different thicknesses, and thus the energy to perforate also differed in each laminate, different impact energies
Table 1

Impact energies used in the tests of the different laminates

\begin{tabular}{lllll}
\hline Laminate & \multicolumn{4}{l}{ Impact energy $(\mathbf{J})$} \\
\hline Cross ply $[0 / 90]_{3 \mathrm{~S}}$ & 1 & 3 & 4 & 6 \\
Quasi isotropic $[ \pm 45 / 0 / 90]_{\mathrm{S}}$ & 2 & 3 & 4 & 5 \\
Woven (10 plies) & 4 & 7 & 10 & 13 \\
\hline
\end{tabular}

were used. Six specimens per laminate and impact energy were tested. All these tests were carried out at room temperature $\left(20{ }^{\circ} \mathrm{C}\right)$.

Each test provided a record of the force applied by the impactor on the specimen and the initial velocity at the moment of impact. From this signal, and under the hypothesis of permanent contact between specimen and impactor, the displacement of the contact point (Eq. (1)) and the absorbed energy up to failure (Eq. (2)) were determined by successive integrations.

$x(t)=x_{0}+\int_{0}^{t}\left[v_{0}-\int_{0}^{t} \frac{F(t)-P}{m} \mathrm{~d} t\right] \mathrm{d} t$
$E(t)=\int_{0}^{t} F(t)\left[v_{0}-\int_{0}^{t} \frac{F(t)-P}{m} \mathrm{~d} t\right] \mathrm{d} t$

\subsection{Compression after impact tests}

A compression test of the impacted specimens was conducted to analyse how its strength was reduced by the impact damage. The compression tests were carried out at low temperatures $\left(-60{ }^{\circ} \mathrm{C}\right.$ and $\left.-150{ }^{\circ} \mathrm{C}\right)$, to reproduce the conditions to which the aeronautical and aerospace structures could be subjected during their service life. The results were compared with CAI tests carried out by the same research team at room temperature $\left(20^{\circ} \mathrm{C}\right)$ [13].

It was not possible to follow the recommendations of ASTM D 7137/D7137M-05 standard [25] since it refers only to the test of laminates thicker than $4 \mathrm{~mm}$, and the thickness of the specimens used in this study was $1.6 \mathrm{~mm}$ in the quasi-isotropic laminate and $2.2 \mathrm{~mm}$ in the crossply and the woven laminate.

For the compression after impact tests, a new device developed by the same research team [13] was used. It allows thin laminates to be tested without altering their geometry in the cutting to make them more slender and thus the damage caused by impact; and the use of tabs is not necessary to perform the compression test, as other authors do $[12,14,15,17]$. This device can be adapted to different specimen thicknesses. It was made of stainless steel for tests at low temperatures.

The device (Fig. 1) was placed in an Instron climatic chamber connected to a universal Instron testing machine of $100 \mathrm{kN}$. The low temperatures were reached using liquid nitrogen. As a means of avoiding erroneous signals due to the cooling of the load cell, it was isolated by a cylindrical tube containing continuously circulating room temperature water. 


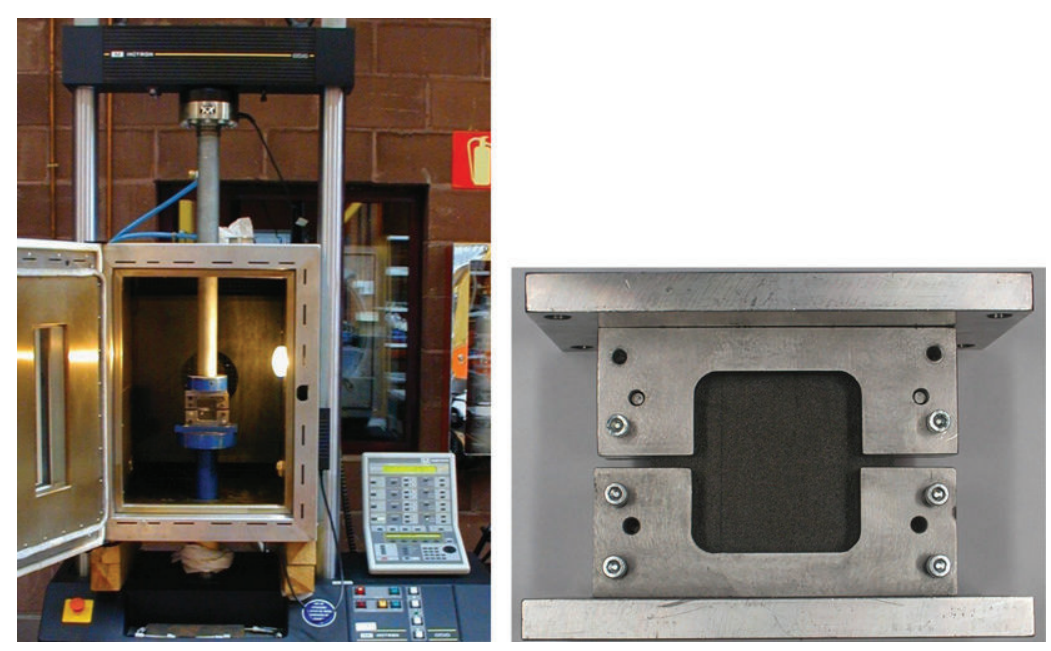

Fig. 1. Test set up (left), with a detail of the compression after impact device (right).

Quasi-static compressive tests were carried out at a constant crosshead-displacement rate of $0.5 \mathrm{~mm} / \mathrm{min}$, three tests for each laminate, impact energy and temperature. Three non-impacted specimens of each laminate and temperature were also tested to determine the variation of residual strength due to the damage produced by impact.

The force applied on each specimen was registered at every instant of time. From the force time curve (Fig. 2) the failure force was determined, this giving the residual strength of the specimen from Eq. (3):

$\sigma_{\mathrm{c}}=\frac{F_{\max }}{w \cdot h}$

where $\sigma_{\mathrm{c}}$ is the ultimate compressive residual strength (MPa), $F_{\max }$ is the maximum force prior to failure $(N), w$ is the width of the specimen $(\mathrm{mm})$ and $h$ is the thickness of the specimen $(\mathrm{mm})$.

Also the compressive-strength-retention factor was determined to gain a better indication of the variation of the residual strength against the impact energy [16]. This

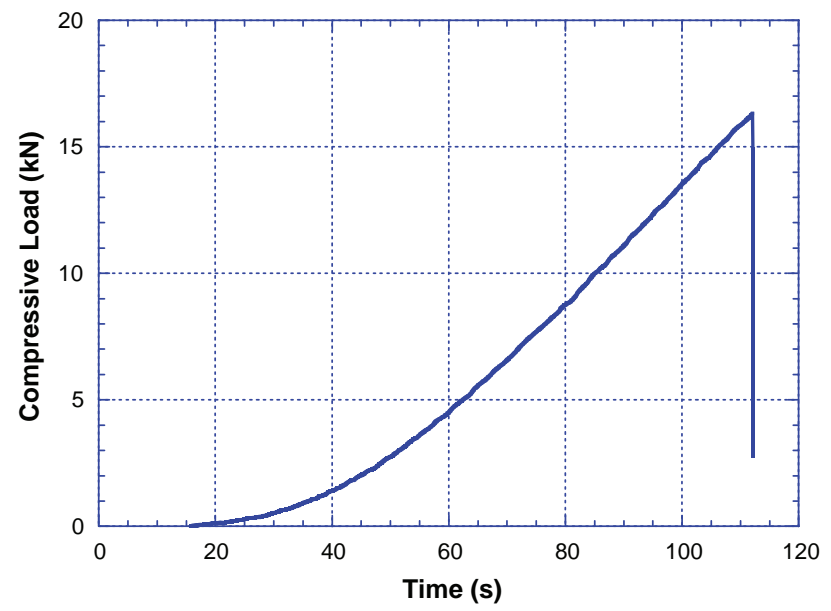

Fig. 2. Force time curve of a compression test at $60^{\circ} \mathrm{C}$ of a quasi isotropic laminate impacted with an energy of $4 \mathrm{~J}$. parameter was defined as the relation between the mean strength of the damaged specimens with a specific impact energy and that of the non-impacted specimen.

\section{Results}

\subsection{Impact tests}

From the force time curve for the impact tests, the absorbed energy was calculated by Eq. (2). Regardless of the impact energy, energy time curves similar to the one in Fig. 3 resulted; that is, a linear rise is shown up to a maximum value (the kinetic energy of the impactor), and then descends to a constant value corresponding to the energy loss due to breakage.

These curves show that the perfectly elastic rebound of the impactor did not take place in any test, nor the perforation of the laminate, but that part of the kinetic energy of the impactor was transferred to the laminate during the contact, and consumed in the generation of damage [26].

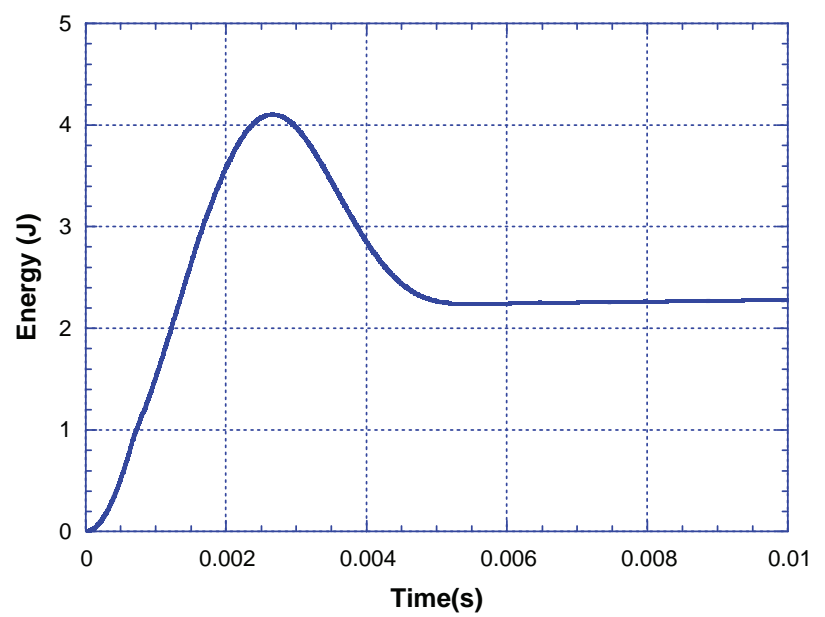

Fig. 3. Energy versus time of the cross ply laminate under an impact of $4 \mathrm{~J}$. 


\subsection{Compression after impact tests}

The mean and the standard deviation of the compression strength were calculated for all the specimens of each laminate tested at the same impact energy and temperature. These values appear in Tables 24 , together with those recorded at room temperature in a previous study [13].

These tables indicate that for some cases, the compressive-strength of the non-impacted specimens shows high dispersion because these specimens are difficult to test to compression because they are exceedingly vulnerable to phenomena such as the global buckling, misalignment, and to the existence of high stress concentration at the specimen ends. The residual strength of the specimens previously damaged proved lower than those of the non-damaged specimens. This was because, during the impact phase, sublaminates with bending stiffness lower than that of a non-impacted laminate were formed, so that under compression these sublaminates buckled locally, and the total failure of the panel takes place at a lower load than in a non-damaged laminate.

From the results of the residual strength and the compressive-strength-retention factor found, the variation in the strength of each laminate with temperature was analysed and the residual behaviour of the different laminates was compared at each test temperature.

Table 2

Compressive strength of cross ply laminate $[0 / 90]_{3 \mathrm{~S}}$, in MPa

\begin{tabular}{llllll}
\hline \multirow{2}{*}{$\begin{array}{l}\text { Test } \\
\text { temperature }\end{array}$} & $\begin{array}{l}\text { Non } \\
\text { impacted }\end{array}$ & \multicolumn{4}{l}{ Impact energy } \\
\cline { 3 - 6 } & & J J & $3 \mathrm{~J}$ & $4 \mathrm{~J}$ & $6 \mathrm{~J}$ \\
\hline $20{ }^{\circ} \mathrm{C}$ & $343 \pm 13$ & $282 \pm 4$ & $196 \pm 8$ & $196 \pm 6$ & $178 \pm 10$ \\
$60^{\circ} \mathrm{C}$ & $283 \pm 19$ & $252 \pm 8$ & $190 \pm 2$ & $173 \pm 15$ & $167 \pm 3$ \\
$150{ }^{\circ} \mathrm{C}$ & $311 \pm 12$ & $263 \pm 24$ & $193 \pm 10$ & $176 \pm 10$ & $146 \pm 10$ \\
\hline
\end{tabular}

Table 3

Compressive strength of quasi isotropic laminate $[ \pm 45 / 0 / 90]_{\mathrm{S}}$, in $\mathrm{MPa}$

\begin{tabular}{llllll}
\hline $\begin{array}{l}\text { Test } \\
\text { temperature }\end{array}$ & $\begin{array}{l}\text { Non } \\
\text { impacted }\end{array}$ & \multicolumn{4}{l}{ Impact energy } \\
\cline { 3 - 6 } & 2 J & 3 J & 4 J & 5 J \\
\hline $20{ }^{\circ} \mathrm{C}$ & $189 \pm 24$ & $152 \pm 10$ & $152 \pm 9$ & $138 \pm 5$ & $132 \pm 14$ \\
$60^{\circ} \mathrm{C}$ & $189 \pm 13$ & $147 \pm 16$ & $147 \pm 4$ & $130 \pm 6$ & $126 \pm 16$ \\
$150{ }^{\circ} \mathrm{C}$ & $189 \pm 6$ & $147 \pm 6$ & $131 \pm 10$ & $123 \pm 12$ & $122 \pm 3$ \\
\hline
\end{tabular}

Table 4

Compressive strength of woven laminate, in MPa

\begin{tabular}{llllll}
\hline $\begin{array}{l}\text { Test } \\
\text { temperature }\end{array}$ & $\begin{array}{l}\text { Non } \\
\text { impacted }\end{array}$ & \multicolumn{4}{l}{ Impact energy } \\
\cline { 2 - 6 } & $4 \mathrm{~J}$ & $7 \mathrm{~J}$ & $10 \mathrm{~J}$ & $13 \mathrm{~J}$ \\
\hline $20{ }^{\circ} \mathrm{C}$ & $357 \pm 5$ & $232 \pm 3$ & $214 \pm 6$ & $195 \pm 13$ & $161 \pm 6$ \\
$60{ }^{\circ} \mathrm{C}$ & $315 \pm 15$ & $272 \pm 9$ & $240 \pm 17$ & $186 \pm 15$ & $160 \pm 8$ \\
$150{ }^{\circ} \mathrm{C}$ & $347 \pm 33$ & $278 \pm 15$ & $264 \pm 20$ & $207 \pm 12$ & $176 \pm 8$ \\
\hline
\end{tabular}

\subsubsection{Influence of temperature on the residual strength of} each laminate

3.2.1.1. Cross-ply laminate [0/90] 3 . At all impact energies, this laminate presented higher residual strength at room temperature than at low temperatures (Table 2). At room temperature, the compressive-strength of the non-impacted specimens was $22 \%$ higher than at $-60{ }^{\circ} \mathrm{C}$ and $10 \%$ than at $-150{ }^{\circ} \mathrm{C}$. Theses values are higher than $7 \%$, that is the variation coefficient observed in this property.

Minor strength variation was noted for an impact energy of $3 \mathrm{~J}$; at room temperature the strength was 3\% higher than for those at $-60{ }^{\circ} \mathrm{C}$ and $1.5 \%$ for those at $-150{ }^{\circ} \mathrm{C}$. This variation is far greater for high-impact energy in which the damaged area was greater. Therefore, at $6 \mathrm{~J}$, the residual strength at room temperature was $7 \%$ and $22 \%$ higher than those of $-60^{\circ} \mathrm{C}$ and $-150^{\circ} \mathrm{C}$, respectively.

A better indication of the variation of the residual strength compared with the reference compressive-strength of the non-impacted specimens was found by analysing the compressive-strength-retention factor.

The influence of the temperature on this parameter is reflected in Fig. 4. At all test temperatures the strengthretention factor sharply diminished from the value found in non-impacted specimens to an impact energy of $3 \mathrm{~J}$. The decrease of the retention factor at this energy was slightly greater in the tests at room temperature, reaching $43 \%$ at $20{ }^{\circ} \mathrm{C}$, close to $32 \%$ at $-60{ }^{\circ} \mathrm{C}$, and $38 \%$ at $-150{ }^{\circ} \mathrm{C}$. From this impact energy, a smaller reduction occurred at all the temperatures. At an impact energy of $6 \mathrm{~J}$, the impact damage had a greater effect when the tests were carried out at $-150{ }^{\circ} \mathrm{C}$, decreasing the retention factor by $52 \%$, whereas reductions of $48 \%$ at $20{ }^{\circ} \mathrm{C}$ and $41 \%$ at $-60{ }^{\circ} \mathrm{C}$ was registered.

The maximum difference in the decrease in the strengthretention factor versus impact energy among the different test temperatures was $10 \%$, with no clear influence from the lower temperature on the reduction of the residual strength.

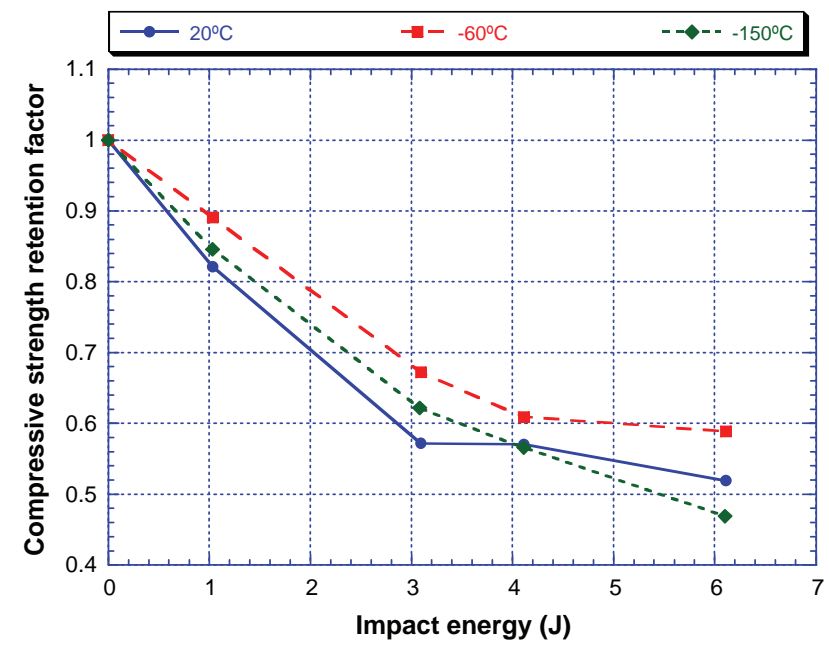

Fig. 4. Compressive strength retention factor versus impact energy in the cross ply laminate. 
Hence, there was no significant influence of the temperature on the compression after impact strength nor on the compressive-strength-retention factor, perhaps because a reduction of the test temperature could trigger contrary effects: on one hand, an increase the matrix stiffness, which would increase the buckling load of the laminate and therefore the compression strength; and, on the other hand, an increase in crack propagation, expanding the delaminated area and augmenting the instability to buckling and thereby diminishing residual strength.

3.2.1.2. Quasi-isotropic laminate $[+45 /-45 / 0 / 90]_{S}$. The non-impacted specimens showed similar compressivestrength at the three test temperatures. When the temperature diminished and the impact energy increased, the residual strength was slightly reduced (Table 3 ). At an impact energy of $2 \mathrm{~J}$, the strength was $3.5 \%$ more at room temperature than at low temperatures, while for an impact energy of $5 \mathrm{~J}$ the residual strength at $20{ }^{\circ} \mathrm{C}$ was $5 \%$ and $8 \%$ greater than at $-60^{\circ} \mathrm{C}$ and $-150{ }^{\circ} \mathrm{C}$, respectively.

Fig. 5 shows a similar variation of the residual strength versus impact energy at $20^{\circ} \mathrm{C}$ and at $-60{ }^{\circ} \mathrm{C}$, and a pronounced decrease at $-150^{\circ} \mathrm{C}$. At an impact of $2 \mathrm{~J}$, the loss of strength was similar, around $20 \%$, at all the test temperatures. Higher impact energies caused damage that exerted greater effects on the retention factor at $-150{ }^{\circ} \mathrm{C}$. At an impact energy of $5 \mathrm{~J}$, the retention factor was reduced by $30 \%$ at room temperature and around $33 \%$ and $36 \%$ at $-60{ }^{\circ} \mathrm{C}$ and $-150{ }^{\circ} \mathrm{C}$, respectively.

As in the cross-ply laminates, in the quasi-isotropic laminate, the influence of temperature on the residual strength and on the strength-retention factor was not significant because the greater matrix stiffness when the temperature diminishes encouraged delamination but also augmented the buckling load.

3.2.1.3. Woven laminate. The mean compressive-strength of non-impacted specimens was slightly weaker at low tem-

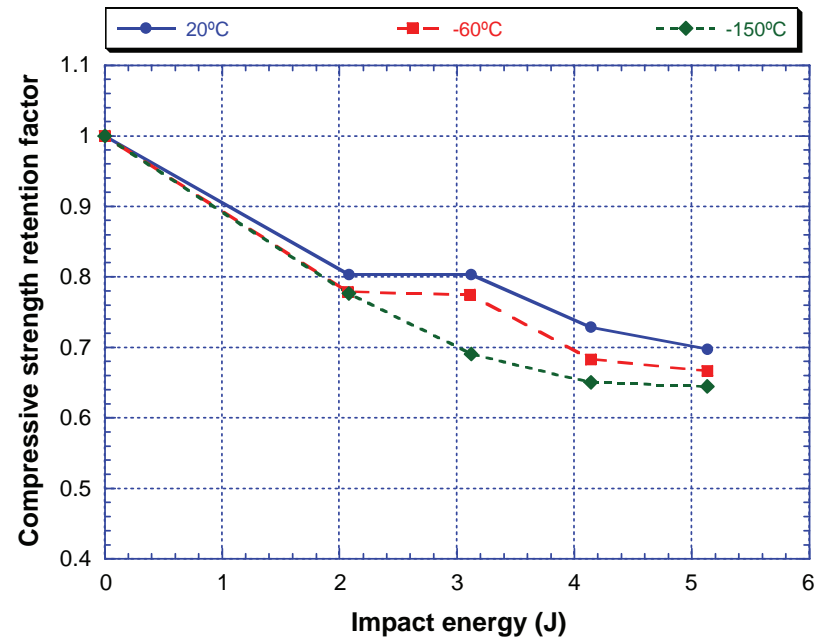

Fig. 5. Compressive strength retention factor versus impact energy in the quasi isotropic laminate.

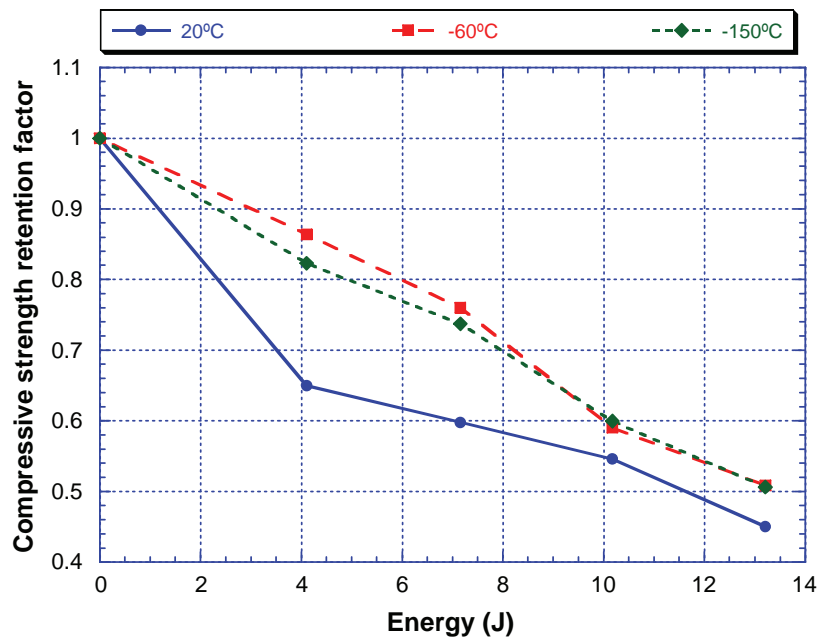

Fig. 6. Compressive strength retention factor versus impact energy in the woven laminate.

peratures than at $20^{\circ} \mathrm{C}$, although this variation was not significant. However, in the damaged specimens, the residual strength proved higher at low temperatures than at room temperature with all the impact energies. For smaller impact energies the difference was greater $\left(17 \%\right.$ at $-60{ }^{\circ} \mathrm{C}$ and $20 \%$ at $-150{ }^{\circ} \mathrm{C}$ ), while at an energy of 10 and $13 \mathrm{~J}$ it was lower $\left(0.6 \%\right.$ at $-60{ }^{\circ} \mathrm{C}$ and $9 \%$ at $-150{ }^{\circ} \mathrm{C}$; Table 3$)$.

Fig. 6 indicates that the impact damage had a more important effect in the decrease of strength at room temperature than at low temperatures. At $20^{\circ} \mathrm{C}$ the reduction in strength for an impact energy of $4 \mathrm{~J}$ was $35 \%$ versus $14 \%$ and $18 \%$ at $-60{ }^{\circ} \mathrm{C}$ and $-150{ }^{\circ} \mathrm{C}$, respectively. At $13 \mathrm{~J}$ the strength diminution was $55 \%$ at room temperature versus $50 \%$ at low temperatures.

The woven laminates show a similar compression after impact behaviour at low temperatures, and a greater reduction of the residual strength and the retention factor at room temperature. This may be due to the effect of the reinforcement architecture that limits crack propagation, and therefore during compression tests prevents the growth of delaminations. Therefore, the dominant effect when the temperature diminishes could be the increased stiffness of the resin that bolsters the bending stiffness of the laminate, implying greater residual strength.

\subsubsection{Comparison of the residual behaviour between the different laminates}

Since the laminates tested had different thicknesses, to compare their variation of the residual strength, the compressive-strength-retention factor was presented versus the impact energy divided by the thickness of the laminate (Figs. 7 and 8). The cross-ply and quasi-isotropic laminates underwent a marked reduction in the residual strength at low impact energies, this reduction being less significant when the impact energy increased. Some researchers [27] have found that the residual compressive-strength drops suddenly near the initial damage range of matrix cracking 


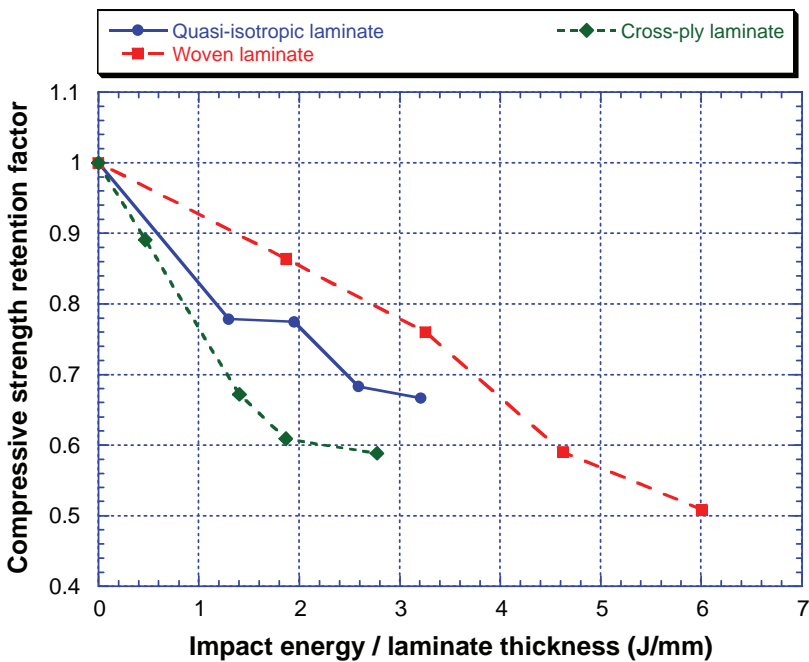

Fig. 7. Compressive strength retention factor versus impact energy/thick ness at $60^{\circ} \mathrm{C}$.

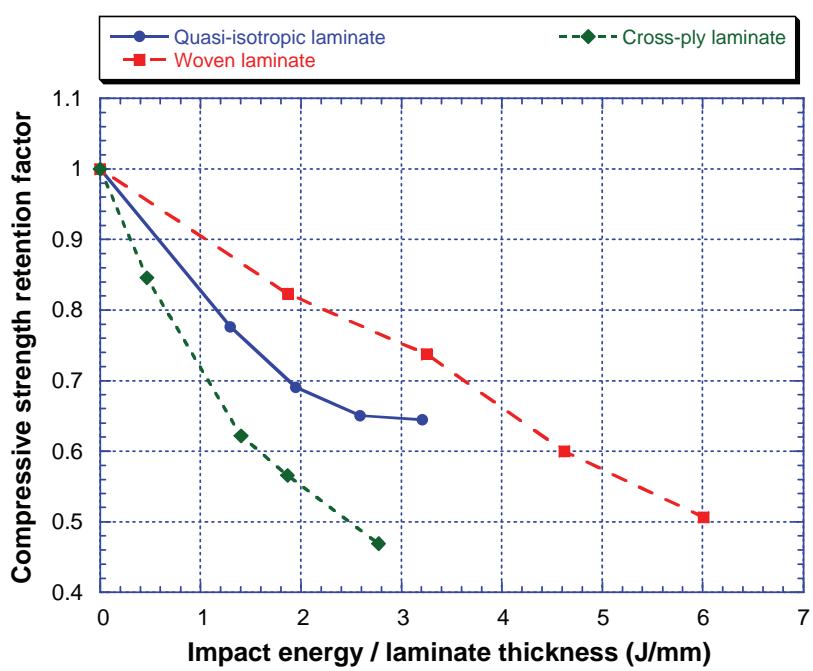

Fig. 8. Compressive strength retention factor versus impact energy/thick ness at $150^{\circ} \mathrm{C}$.

and the initial delamination. This would explain why in the woven laminate the decrease in residual strength with the impact energy had a smaller slope, since the architecture of the reinforcement blocks the matrix cracking and the delamination, and the initial damage takes place at higher energies than in tape laminates.

The differences between the compressive-strength of non-impacted specimens in all the tested laminates were similar at $-60{ }^{\circ} \mathrm{C}$ and at $-150{ }^{\circ} \mathrm{C}$ (Tables 24 ). The woven laminate shows a strength $10 \%$ higher than the cross-ply laminates and $65 \%$ higher than the quasi-isotropic laminates, because in the last laminate the proportion of laminas oriented in the load direction was smaller.

Figs. 7 and 8 show that at low temperatures $\left(-60^{\circ} \mathrm{C}\right.$ and $-150{ }^{\circ} \mathrm{C}$ ), the impact damage influences more the decrease in compressive residual strength in the cross-ply laminate, while the woven laminates presents the least loss of strength. At an impact energy of $2 \mathrm{~J} / \mathrm{mm}$ and a temperature of $-60{ }^{\circ} \mathrm{C}$, the woven laminates registered a decline in the retention factor around $15 \%, 22 \%$ in the quasi-isotropic laminates and roughly $40 \%$ in the cross-ply laminates. At $-150{ }^{\circ} \mathrm{C}$, and an impact energy of $2 \mathrm{~J} / \mathrm{mm}$, the retention factor fell $18 \%$ in the woven laminate, $32 \%$ in the quasi-isotropic laminates, and $45 \%$ in the cross-ply laminates.

The loss of the residual strength was greater in the tape laminates (cross-ply and quasi-isotropic) than in the woven laminates because the delamination that occurred in the former, at the same impact energy, was far greater. A larger delaminated area was reported by Gómez-del Rio et al. [28] in the laminates used in the present work, impacted at the same energies. A greater delamination could increase the buckling instability, diminishing the residual strength, and the reinforcement architecture of the woven laminate restrains the shear cracking and the growth of the delamination, which in turn provides greater residual compressive-strength.

In the work of Gómez del Rio et al. [28] greater delamination of the quasi-isotropic laminate than the cross-ply laminate was found at the same impact energies. This could explain why this laminate presents the lowest residual compressive-strength (Tables 2 and 3). The strength-retention factor shows less variation of the residual strength in the quasi-isotropic laminates than in the cross-ply laminates, since the $\pm 45^{\circ}$ plies placed on the surface of the laminates protect the load bearing $0^{\circ}$ plies against impact damage. The cross-ply laminates underwent the most severe reduction in the residual strength, probably because its middle plies are oriented at $90^{\circ}$, and therefore the possible middle sublaminate, which could be formed during the impact test, has little stability in compression due to its smaller buckling stiffness, and its failure will take place a lower force than that required for the failure of the non-impacted laminates.

\section{Conclusions}

The main conclusions are:

At all test temperatures, the different laminates presented a similar tendency in the variation of residual strength with the impact energy. When the impact energy increased, and therefore the damage in the specimen was larger, the compression after impact strength significantly declined, tending to a constant value at higher energies.

The influence of temperature on the residual strength and the compressive-strength-retention factor were not significant in tape laminates, but in the woven laminate the low temperatures provoked smaller decreases in the residual strength than at room temperature.

At all the impact energies and temperatures used in the compression after impact tests, the woven laminate presented higher residual strength than the tape laminates, and the quasi-isotropic laminate the lowest. With regard 
to the strength-retention factor, the cross-ply laminate showed the worst damage tolerance and the woven laminates the highest retention factor. The behaviour of the latter laminate may be due to the contention of the shear cracking and delamination that exercise the architecture of their reinforcement.

\section{Acknowledgement}

The authors are indebted to the Spanish Comisión Interministerial de Ciencia y Tecnología (Project MAT-98/0273) for the financial support of this work.

\section{References}

[1] Kumagai S, Shindo Y, Horiguchi K, Narita F. Experimental and finite analysis of woven glass cloth/epoxy laminate tensile specimen at room and low temperatures. Mech Adv Mater Struct 2004;11:51 66 .

[2] Aoki T, Ishikawa T, Kumazawa H, Morino Y. Cryogenic mechanical properties of $\mathrm{CF} /$ polymer composites for tanks of reusable rockets. Adv Compos Mater 2001;10(4):349 56.

[3] Guerrero J, Hamilton B, Burton R, Crokett D, Taylor Z. Upper stage flight experiment (USFE) integral structure development effort. Compos Struct 2004;66:327 37.

[4] Tomassetti G, Barboni R, Benedetti M. Optimisation methodology for cryotanks. Comput Struct 2005;83:2293 305.

[5] Ifju P, Myers D, Schulz W. Residual stress and thermal expansion of graphite epoxy laminates subjected to cryogenic temperatures. Compos Sci Technol 2006;66:2449 55.

[6] Miyano Y, Kanemitsu M, Kunio T, Kuhn HA. Role of matrix resin on fracture strengths of unidirectional CFRP. J Compos Mater 1986;20:520 38 .

[7] Winkel JD, Adams DF. Instrumented drop weight impact testing of cross ply and fabric composites. Composites 1985;16(4):268 78.

[8] Im KH, Cha CS, Kim SK, Yang IY. Effects of temperature on impact damages in CFRP composite laminates. Compos Part B: Eng 2001;32:669 82 .

[9] Kinsey A, Saunders DEJ, Soutis C. Post impact compressive behav iour of low temperature curing woven CFRP laminates. Composites 1995;26(9):661 7

[10] Baker AA, Jones R, Callinan RJ. Damage tolerance of graphite/ epoxy composites. Compos Struct 1985;4:15 44.

[11] Prichard JC, Hogg PJ. The role of impact damage in post impact compression testing. Composites 1990;21(6):503 11.
[12] Hawyes VJ, Curtis PT, Soutis C. Effect of impact damage on the compressive response of composite laminates. Compos Part A: Appl Sci Manufact 2001;32(9):1263 70.

[13] Sanchez Saez S, Barbero E, Zaera R, Navarro C. Compression after impact of thin composite laminates. Compos Sci Technol 2005;65(13):19119.

[14] Sjoblom PO, Hwang B. Compression after impact: The \$5,000 data point! Int SAMPE Symp Exhibit 1989;34:1411 21.

[15] Nettles AT, Hodge AJ. Compression after impact testing of thin composite materials. In: Proceedings of the 23rd international SAMPE technical conference; 1991, p. 17783.

[16] Abrate S. Impact on composite structures. New York: Cambridge University Press; 1998.

[17] Liu D, Raju BB, Dang X. Size effects on impact response of composite laminates. Int J Impact Eng 1998;21(10):837 54.

[18] Byun J H, Song S W, Lee C H, Um M K, Hwang B S. Impact properties of laminated composites with stitching fibers. Compos Struct 2006;76(1 2):21 7 .

[19] Petersen D, Rolfes R, Zimmermann R. Thermo mechanical design aspects for primary composite structures of large transport aircraft. Aerospace Sci Technol 2001;5:135 46

[20] Reed RP, Golda M. Cryogenic properties of unidirectional compos ites. Cryogenics 1994;11:909 28.

[21] Timmerman JF, Tillman MS, Hayes BS, Seferis JC. Matrix and fiber influences on the cryogenic microcracking of carbon fiber/epoxy composites. Compos Part A Appl Sci Manufact 2002;33(3):323 9.

[22] Kellogg KG, Kallmeyer AR, Dutta PK. Influence of moisture and reduced temperature thermal cycles on the Izod notch toughness of a pultruded glass fiber composite. Int J Offshore Polar Eng 2003;13(3): 2329.

[23] Schutz JB. Properties of composite materials for cryogenic applica tions. Cryogenics 1998;38:3 12.

[24] Pintado JM, Carrión JG, García JL, Blas F. Mechanical behavior of composite materials at cryogenic temperature. In: Proceedings of 4 th European conference of composites: testing and standard, 1998. p. 93102.

[25] ASTM D7137/D7137M 05. Standard test method for compressive residual strength properties of damaged polymer matrix composite plates. 2005.

[26] Scarponi C, Briotti G, Barboni R, Marcone A, Iannone M. Impact testing on composites laminates and sandwich panels. J Compos Mater 1996;30(17):1873 911.

[27] Kim JH, Kim DH, Kim HS, Park BJ. A study on low velocity impact of woven glass/phenolic composite laminates considering environ mental effects. Key Eng Mater 2005;297 300:1303 8.

[28] Gómez del Río T, Zaera R, Barbero E, Navarro C. Damage in CFRPs due to low velocity impact at low temperature. Compos Part B: Eng 2005;36(1):41 50. 